\title{
STATUS GIZI ANAK SEKOLAH DASAR DI KECAMATAN SIBOLGA SAMBAS, KOTA SIBOLGA
}

\author{
Bibi Ahmad Chahyanto ${ }^{*}$, Edwin Sovvan Aritonang ${ }^{2}$, Mesa Laruska ${ }^{3}$ \\ 1. Seksi Kesehatan Keluarga \& Gizi, Dinas Kesehatan Kota Sibolga, Sibolga-Indonesia \\ 2. UPTD Puskesmas Pelabuhan Sambas, Sibolga-Indonesia \\ 3. UPTD Puskesmas Pelabuhan Sambas, Sibolga-Indonesia
}

*Korespondensi: Bibi Ahmad Chahyanto | Dinas Kesehatan Kota Sibolga | bibiahmadchahyanto@gmail.com

\begin{abstract}
Abstrak
Pendahuluan: Masalah gizi pada anak sekolah dasar saat ini masih relatif tinggi. Salah satu cara memantau status gizi anak sekolah yaitu melalui program penjaringan peserta didik baru sekolah dasar. Studi ini bertujuan untuk menganalisis gambaran status gizi dan prevalensi kegemukan, kekurusan, dan kependekan pada siswa baru masuk sekolah dasar di Kecamatan Sibolga Sambas, Kota Sibolga.

Metode: Studi potong lintang ini melibatkan 344 siswa kelas 1 yang berasal dari tujuh sekolah dasar di wilayah kerja Puskesmas Pelabuhan Sambas. Siswa dipilih menjadi responden dengan teknik total sampling menggunakan kriteria inklusi. Pengukuran tinggi dan berat badan dilakukan pada seluruh responden untuk selanjutnya indeks massa tubuh (IMT) dihitung untuk masing-masing responden. Pengumpulan data dilakukan oleh tenaga kesehatan puskesmas yang terdiri dari ahli gizi, bidan, perawat, dan penyuluh kesehatan pada bulan Agustus hingga September 2017.

Hasil: Hasil studi membuktikan bahwa tidak terdapat perbedaan yang signifikan untuk rata-rata indeks massa tubuh dan tinggi badan antara responden laki-laki dengan perempuan. Perbedaan yang signifikan hanya ditunjukkan pada rata-rata indeks massa tubuh dan tinggi badan antara siswa yang bersekolah di sekolah negeri dan swasta. Prevalensi kegemukan, kekurusan, dan kependekan sebesar 4,94\%, 15,12\%, dan 3,78\%.

Kesimpulan: Angka prevalensi yang tersedia ini dapat menambah database status gizi anak sekolah serta dijadikan acuan dalam menentukan kebijakan dan program intervensi sensitif dan spesifik untuk mencegah peningkatan prevalensi kekurusan dan kependekan, serta menurunkan kegemukan.
\end{abstract}

Kata Kunci : Anak Usia Sekolah, Kota Sibolga, Status gizi.

Diterima 24 Januari 2019; Accepted 30 Juni 2019

\section{PENDAHULUAN}

Anak usia sekolah dasar merupakan kelompok anak dengan umur antara 6 tahun hingga 12 tahun yang duduk di bangku Sekolah Dasar (SD), Madrasah Ibtidaiyah (MI) atau bentuk pendidikan lainnya yang sederajat (PP No. 17, 2010). Status gizi dan kesehatan yang optimal pada kelompok ini penting dijaga untuk membantu proses pertumbuhan dan perkembangan, berpikir, aktivitas fisik yang optimal, serta menjaga daya tahan tubuh sehingga dapat menunjang kegiatan belajar di sekolah (Sa'adah et al., 2014; Maleke et al., 2015).

Faktanya, masalah gizi pada anak sekolah dasar saat ini masih relatif tinggi. Hasil review sistematis yang dilakukan Best, et al. (2010) membuktikan bahwa prevalensi stunting, underweight, dan overweight (termasuk obesitas) pada anak usia sekolah di Asia tenggara masih cukup tinggi yaitu 29\%, 39\%, dan 13\%. Data hasil Riset Kesehatan Dasar (RISKESDAS) tahun 2013 menunjukkan bahwa prevalensi kependekan, kekurusan, dan kegemukan pada anak usia 5-12 tahun di Indonesia masih tinggi yaitu 30,7\%, 11,2\%, dan $18,8 \%$. Provinsi Sumatera Utara termasuk salah satu provinsi dengan angka prevalensi kegemukan dan kependekan pada anak usia 5 - 12 tahun yang berada di atas angka nasional yaitu 21,2\% dan 36,9\%, sedangkan prevalensi kekurusan berada di bawah angka nasional yaitu sebesar 9,3\% (Kemenkes RI, 2013).

Kota Sibolga merupakan salah satu kota di Provinsi Sumatera Utara yang terletak di wilayah pesisir Pantai Barat Pulau Sumatera. Kota Sibolga termasuk ke dalam kabupaten/kota yang memiliki angka prevalensi kekurusan dan kegemukan pada usia 5-12 tahun yang berada di atas Provinsi Sumatra Utara, yaitu 14,9\% dan 12,8\% (Kemenkes RI, 2013).

Salah satu program yang dilaksanakan oleh Dinas Kesehatan Kota Sibolga yang diteruskan kepada UPTD Puskesmas sesuai dengan arahan Kementerian Kesehatan RI adalah Penjaringan Kesehatan Peserta Didik. Program ini bertujuan untuk meningkatkan derajat kesehatan peserta didik secara optimal (Kemenkes RI, 2010). Salah satu kunci optimalnya derajat kesehatan adalah optimalnya status gizi. Oleh 
karena itu, pengukuran Tinggi Badan (TB) dan Berat Badan (BB) menjadi salah satu kegiatan wajib yang dilakukan saat pelaksanaan penjaringan untuk menentukan dan memantau status gizi. Data status gizi ini dapat dijadikan acuan dalam menentukan prevalensi kependekan, kekurusan, dan kegemukan khususnya pada Siswa Sekolah Dasar di Kota Sibolga.

UPTD Puskesmas Pelabuhan Sambas merupakan puskesmas di wilayah kerja Kecamatan Sibolga Sambas, Kota Sibolga yang menjalankan program Penjaringan Kesehatan Peserta Didik Sekolah Dasar dan melakukan penilaian status gizi dari data yang ada. Oleh karena itu, studi ini bertujuan untuk menganalisis gambaran status gizi dan menghitung prevalensi kegemukan, kekurusan, dan kependekan pada siswa baru masuk Sekolah Dasar (SD)/ sederajat di Kecamatan Sibolga Sambas, Kota Sibolga.

\section{METODE}

Studi ini menggunakan data hasil pelaksanaan Program Penjaringan Peserta Didik Baru Sekolah Dasar/sederajat (SD/sederajat) Tahun Ajaran (TA) 2017/2018 di wilayah kerja UPTD Puskesmas Pelabuhan Sambas, Kecamatan Sibolga Sambas. Desain studi yang digunakan adalah studi potong lintang (cross sectional study).

Program penjaringan peserta didik baru SD/sederajat kelas 1 TA 2017/2018 di wilayah kerja UPTD Puskesmas Pelabuhan Sambas dilakukan pada bulan Agustus - September 2017. Jumlah SD/sederajat di wilayah kerja UPTD Puskesmas Pelabuhan Sambas sebanyak 7 sekolah yang menjadi lokasi kegiatan penjaringan. Sekolah- sekolah tersebut terdiri dari MI Swasta Almuhlisin, MI Swasta Nurul Falah, SD Swasta Nurul Falah, SD Swasta Muhammadiyah 3, SD Negeri 081228, SD Negeri 084094, dan SD Negeri 091239.

Populasi dalam program penjaringan ini adalah seluruh siswa SD/sederajat kelas 1 TA 2017/2018 di 7 sekolah wilayah kerja UPTD Puskesmas Pelabuhan Sambas yaitu sebanyak 374 siswa. Metode sampling yang digunakan adalah total sampling yaitu seluruh siswa yang memenuhi kriteria inklusi dijadikan sebagai responden dalam program penjaringan. Kriteria inklusi dalam program ini adalah siswa hadir di sekolah dan bersedia mengikuti seluruh rangkaian pengukuran dan penilaian kesehatan pada saat program penjaringan dilakukan, serta memiliki data nama, jenis kelamin, status sekolah, umur (U), tinggi badan (TB), dan berat badan (BB) yang jelas. Data-data tersebut dikumpulkan oleh tenaga kesahatan puskesmas terlatih yang melakukan penjaringan kesehatan, terdiri dari ahli gizi, bidan, perawat, dan penyuluh kesehatan. Data TB diukur menggunakan alat stature meter ketelitian $0,1 \mathrm{~cm}$, dan BB diukur menggunakan timbangan injak digital ketelitian $0,1 \mathrm{~kg}$.

Total responden yang menjadi sampel dan diolah lebih lanjut sebanyak 344 siswa. Sebanyak 30 siswa mengalami ekslusi karena tidak memiliki data U, BB, dan TB yang lengkap. Data yang telah lengkap selanjutnya dimasukkan ke dalam program komputer microsoft excell untuk perhitungan Indeks Massa Tubuh (IMT) masing-masing siswa.

Status gizi siswa ditentukan menggunakan indeks IMT menurut umur (IMT/U) dan TB menurut umur (TB/U). Status gizi berdasarkan indeks IMT/U pada siswa menggunakan ambang batas dan kategori tabel $z$-score sesuai Keputusan menteri Kesehatan Republik Indonesia Nomor: 1995/MENKES/ SK/XII/2010 tentang Standar Antropometri Penilaian Status Gizi Anak. Status gizi anak berdasarkan indeks TB/U menggunakan ambang batas pada Cakram Pemantauan Tinggi Badan yang diproduksi oleh Perhimpunan Pakar Gizi dan Pangan Indonesia (PERGIZI PANGAN Indonesia) yang menggunakan acuan Organisasi Kesehatan Dunia (WHO).

Data yang ada dan telah diolah selanjutnya disajikan dalam bentuk tabel distribusi frekuensi dan dijelaskan secara deskriptif. Analisis lanjutan independent t- test menggunakan software SPSS 16 for Windows untuk menganalisa perbedaan karakteristik antropometri antara siswa laki- laki dengan perempuan dan antara siswa yang bersekolah di sekolah milik pemerintah (sekolah negeri) dengan siswa yang bersekolah di sekolah milik yayasan/perorangan (sekolah swasta). Hasil analisis statistik tersebut dinyatakan berbeda secara nyata (signifikan) apabila nilai $\mathrm{p}<0,05$.

\section{HASIL}

Siswa SD/sederajat kelas 1 di Kecamatan Sibolga Sambas yang menjadi responden berumur $4-10$ tahun dengan rata- rata umur 6,07 $\pm 0,73$ tahun. Dari 344 siswa, sebanyak 83,14\% berumur $6-7$ tahun. Responden laki-laki mendominasi pada studi ini dengan proporsi jumlah yang lebih tinggi jika 
dibandingkan dengan responden perempuan, yaitu sebanyak 51,16\% (Tabel 1). Jumlah $\quad$ SD/ sederajat di Kecamatan Sibolga Sambas sebanyak 7 sekolah. Jika dikelompokkan berdasarkan status sekolah, sebanyak 4 sekolah di Kecamatan Sibolga Sambas berstatus milik yayasan/pribadi (sekolah swasta) dan 3 sekolah berstatus milik pemerintah (sekolah negeri). Proporsi siswa pada sekolah negeri lebih tinggi $(60,76 \%)$ dibandingkan dengan siswa sekolah swasta $(39,24 \%)$ (Tabel 1).

Status gizi responden berdasarkan indeks IMT/U dikategorikan menjadi Sangat Kurus, Kurus, Normal, Gemuk, dan Obesitas. Hasil studi menunjukkan prevalensi kekurusan (sangat kurus dan kurus) pada responden sebesar $15,12 \%$ dan prevalensi kegemukan (gemuk dan obesitas) sebesar 4,94\%. Prevalensi kekurusan pada siswa laki- laki $(9,60 \%)$ lebih tinggi dibandingkan dengan siswa perempuan $(5,2 \%)$. Sebaliknya, prevalensi kegemukan pada siswa laki-laki $(2,32 \%)$ sedikit lebih rendah dibandingkan dengan siswa perempuan $(2,62 \%)$ (Tabel 2). Rata-rata IMT siswa laki-laki $\left(14,58 \pm 2,26 \mathrm{~kg} / \mathrm{m}^{2}\right)$ secara statistik tidak berbeda signifikan dengan rata-rata IMT siswa perempuan $\left(14,32 \pm 1,66 \mathrm{~kg} / \mathrm{m}^{2}\right)$ dengan nilai $\mathrm{p}=0,227$ $(\mathrm{p}>0,05)$.

Tabel 2 menunjukkan bahwa prevalensi kekurusan dan kegemukan pada siswa yang bersekolah di $\mathrm{SD} /$ sederajat Negeri lebih tinggi $(8,15 \%$ dan 4,36\%) dibandingkan dengan SD/sederajat Swasta (6,97\% dan $0,58 \%)$. Rata-rata IMT siswa yang bersekolah di SD/sederajat Negeri $\left(14,67 \pm 2,25 \mathrm{~kg} / \mathrm{m}^{2}\right)$ secara statistik berbeda signifikan dengan rata-rata IMT siswa yang bersekolah di SD/sederajat Swasta $(14,13 \pm$ $\left.1,45 \mathrm{~kg} / \mathrm{m}^{2}\right)$ dengan nilai $\mathrm{p}=0,007(\mathrm{p}<0,05)$.

Status gizi responden berdasarkan indeks $\mathrm{TB} / \mathrm{U}$ dikategorikan menjadi kependekan, ideal, dan tinggi. Hasil studi menunjukkan prevalensi kependekan pada siswa laki-laki $(3,20 \%)$ lebih tinggi dibandingkan dengan perempuan $(0,58 \%)$ (Tabel 3$)$. Siswa laki-laki memiliki rata-rata tinggi badan yang sedikit lebih tinggi $(112,10 \pm 5,55 \mathrm{~cm})$ daripada siswa perempuan $(111,49 \pm 5,06 \mathrm{~cm})$. Secara statistik tidak terdapat perbedaan yang signifikan antara tinggi badan keduanya.

Tabel 1. Distribusi Karakteristik Responden berdasarkan Umur, jenis Kelamin, dan Status Sekolah

\begin{tabular}{lcc}
\hline \multicolumn{1}{c}{ Karakteristik } & Frekuensi (n) & Persentase (\%) \\
\hline Umur & & \\
$4-5$ tahun & 46 & 13,37 \\
$6-7$ tahun & 286 & 83,14 \\
$8-10$ tahun & 12 & 3,49 \\
\hline Jenis Kelamin & & \\
Laki-laki & 176 & 51,16 \\
Perempuan & 168 & 48,84 \\
\hline Status Sekolah & & \\
Negeri & 209 & 60,76 \\
Swasta & 135 & 39,24 \\
\hline TOTAL & 344 & 100 \\
\hline
\end{tabular}

Tabel 2. Prevalensi Parameter Status Gizi Indeks IMT/U Siswa Baru Masuk SD kelas 1 berdasarkan Jenis Kelamin dan Status Sekolah di Kecamatan Sibolga Sambas

\begin{tabular}{lcccccc}
\hline \multirow{2}{*}{$\begin{array}{c}\text { Parameter Status } \\
\text { Gizi Indeks IMT/U* }\end{array}$} & \multicolumn{5}{c}{ Prevalensi / Prevalence Rate (\%) } \\
\cline { 2 - 7 } & Laki-laki & Perempuan & Total & Negeri & Swasta & Total \\
\cline { 2 - 7 } & 2,91 & 1,16 & 4,07 & 2,33 & 1,74 & 4,07 \\
Sangat Kurus & 6,69 & 4,36 & 11,05 & 5,82 & 5,23 & 11,05 \\
Kurus & 39,24 & 40,70 & 79,94 & 48,25 & 31,69 & 79,94 \\
Normal & 1,16 & 2,04 & 3,20 & 2,62 & 0,58 & 3,20 \\
Gemuk & 1,16 & 0,58 & 1,74 & 1,74 & 0 & 1,74 \\
Obesitas & 51,16 & 48,84 & 100 & 60,76 & 39,24 & 100 \\
\hline TOTAL & &
\end{tabular}

Keterangan : *) IMT/U = Indeks Massa Tubuh menurut Umur 
Tabel 3. Prevalensi Parameter Status Gizi Indeks TB/U Siswa Baru Masuk SD kelas 1 berdasarkan Jenis Kelamin dan Status Sekolah di Kecamatan Sibolga Sambas

\begin{tabular}{lcccccc}
\hline \multirow{2}{*}{$\begin{array}{c}\text { Parameter Status } \\
\text { Gizi Indeks TB/U* }\end{array}$} & \multicolumn{5}{c}{ Prevalensi / Prevalence Rate (\%) } \\
\cline { 2 - 7 } & Laki-laki & Perempuan & Total & Negeri & Swasta & Total \\
\cline { 2 - 7 } & 3,20 & 0,58 & 3,78 & 0,87 & 2,91 & 3,78 \\
Kependekan & 47,67 & 46,52 & 94,19 & 58,72 & 35,47 & 94,19 \\
Ideal & 0,29 & 1,74 & 2,03 & 1,16 & 0,87 & 2,03 \\
Tinggi & 51,16 & 48,84 & 100 & 60,75 & 39,25 & 100 \\
\hline TOTAL & &
\end{tabular}

Keterangan : *) TB/U = Indeks Tinggi Badan menurut Umur

Berkebalikan dengan prevalensi kekurusan dan kegemukan, prevalensi kependekan pada siswa yang bersekolah di SD/sederajat Negeri lebih rendah $(0,87 \%)$ dibandingkan dengan siswa di SD/sederajat Swasta $(2,91 \%)$ (Tabel 3). Secara statistik, terdapat perbedaan yang signifikan $(p=0,041 ; p<0,05)$ antara rata-rata tinggi badan siswa yang bersekolah di sekolah $\mathrm{SD} /$ sederajat Negeri $(112,27 \pm 5,9 \mathrm{~cm})$ dibandingkan dengan siswa di SD/sederajat Swasta $(111,07 \pm 5,59 \mathrm{~cm})$.

\section{PEMBAHASAN}

Peraturan Menteri Pendidikan dan Kebudayaan Republik Indonesia Nomor 17 Tahun 2017 menjelaskan bahwa calon peserta didik baru kelas satu SD atau bentuk lain sederajat berusia paling rendah 6 tahun pada tanggal 1 Juli tahun berjalan. Faktanya, hasil studi ini menunjukkan masih ditemukannya siswa baru masuk kelas $1 \mathrm{SD} /$ sederajat yang berumur $4-5$ tahun (13,37\%). Hasil yang diperoleh ini tidak jauh berbeda dengan penelitian Mariyati (2017) yang menunjukkan bahwa masih ada sebanyak 16\% calon siswa berumur kurang dari 6 tahun yang terdaftar dalam lembaga pendidikan.

Umur siswa pada saat baru masuk SD berhubungan dengan kesiapan dan kematangan siswa. Semakin tinggi umur siswa, akan semakin meningkat pula tingkat kematangan siswa secara signifikan (Mariyati, 2017). Namun, umur siswa pada saat baru masuk SD tidak selalu menjadi faktor penghambat prestasi belajar. Menurut Kustimah \& Kusumawati (2007) dalam Mariyati (2017), faktor-faktor lain yang mempengaruhi kesiapan dan kematangan anak untuk masuk SD selain umur adalah kesehatan fisik, tingkat kecerdasan, stimulasi yang tepat, serta emosi. Rizally (2014) membuktikan bahwa tidak terdapat hubungan yang signifikan antara umur siswa saat baru masuk SD dengan prestasi belajar. Namun, perlu diperhatikan juga aturan dan regulasi pemerintah yang mengisyaratkan bahwa umur yang tepat bagi anak untuk masuk ke SD paling rendah 6 tahun dan anak umur di bawah 6 tahun diperkenankan tetapi harus ada rekomendasi dari psikolog profesional.

Studi ini membuktikan bahwa masih ditemukannya kependekan (pendek dan sangat pendek), kekurusan (kurus dan sangat kurus), dan kegemukan (gemuk dan obesitas) pada siswa baru masuk $\mathrm{SD} /$ sederajat kelas 1 di Kecamatan Sibolga Sambas meskipun prevalensinya tidak tinggi. Status gizi yang mendominasi pada studi ini adalah status gizi normal berdasarkan indeks IMT/U (79,94\%). Hasil ini sejalan dengan Jahri et al. (2016) yang membuktikan bahwa mayoritas siswa SD di Kecamatan Siak Kecil, Kabupaten Bengkalis memiliki status gizi yang normal berdasarkan indeks IMT/U (76\%). Hasil yang tidak jauh berbeda ditunjukkan juga oleh Ningsih et al. (2016) yang membuktikan prevalensi status gizi normal (IMT/U) pada siswa SD di Kecamatan Rangsang, Kabupaten Kepulauan Meranti sebesar 71,90\%. Di wilayah berbeda, Purnamasari et al. (2016) juga membuktikan bahwa status gizi indeks IMT/U siswa baru masuk SD di perkotaan sebesar 70,5\%. Sebaliknya, hasil studi ini lebih tinggi dari prevalensi status gizi normal pada anak SD di Kecamatan Bangko, Kabupaten Rokan Hilir yang hanya sebesar 44,3\% (Lestari et al., 2016). Status gizi normal dapat diperoleh melalui konsumsi makanan bergizi yang cukup serta metabolisme zat gizi dalam tubuh secara efisien (Almatsier, 2006). Status gizi yang optimal akan mempengaruhi tumbuh kembang anak, termasuk perkembangan intelektualnya yang berdampak pada prestasi belajar (Sa'adah et al., 2014).

Kekurusan merupakan manifestasi akibat tidak tercukupinya kebutuhan satu atau lebih zat gizi yang diperlukan oleh tubuh. Kondisi ini akan menghambat tumbuh kembang anak, menurunkan kekebalan 
tubuh, menurunkan produktivitas kerja, serta sulitnya menerima pengetahuan / berkonsentrasi (Sulistyoningsih, 2011; Sa'adah et al., 2014). Faktor risiko terjadinya kekurusan pada anak SD adalah pendapatan orangtua dan tingkat pendidikan yang rendah (Ningsih et al., 2016; Jahri et al., 2016 ).

Prevalensi kegemukan (IMT/U) pada siswa baru kelas 1 SD di Kecamatan Sibolga Sambas pada studi ini $(4,94 \%)$ lebih kecil jika dibandingkan prevalensi kegemukan pada anak $5-12$ tahun di Provinsi Sumatera Utara yaitu 21,2\% (Kemenkes RI, 2013) dan prevalensi status gizi anak baru masuk SD di perkotaan yaitu sebesar 27,3\% (Purnamasari et al., 2016). Hasil studi ini, hampir sama dengan prevalensi kegemukan pada siswa SD di Kecamatan Bangko, Kabupaten Rokan Hilir yaitu sebesar 4,3\% (Lestari et al., 2016). Faktor-faktor yang menjadi penyebab kegemukan pada anak sekolah di Indonesia adalah bertempat tinggal di wilayah perkotaan, peningkatan pendapatan keluarga, kesukaan menonton televisi atau bermain Play Station, transportasi yang digunakan saat berangkat ke sekolah, dan konsumsi makanan cepat saji (Fast Foods). Meningkatnya pendapatan keluarga dapat berdampak pada perubahan pola konsumsi makanan keluarga. Kecenderungan untuk mengonsumsi makanan siap saji dan berlemak tinggi dengan harga yang relatif mahal akan meningkat. Konsumsi ini tidak diimbangi dengan konsumsi pangan berserat serta aktivitas fisik yang cukup sehingga akan berakibat pada timbunan lemak tubuh (Collins et al., 2008; Purnamasari et al., 2016; Rachmi et al., 2017).

Kondisi kegemukan sangat berbahaya bagi anak usia sekolah. Penelitian Baker, Olsen \& Sorensen (2007) membuktikan adanya peningkatan risiko penyakit jantung hingga 33\% saat dewasa pada anak yang mengalami kegemukan pada umur 7 - 13 tahun. Menurut Katier et al. (2008), obesitas sering dikaitkan dengan adanya abnormalitas metabolik seperti dislipidemia, resistensi insulin, hiperglikemia dan hipertensi yang dapat meningkatkan risiko penyakit kardiovaskuler. Oleh karena itu, obesitas pada anak usia sekolah harus dicegah. Studi meta analisis yang dilakukan oleh Djaiman et al. (2017) membuktikan bahwa aktivitas fisik dan perilaku makan yang sehat dapat mencegah terjadinya obesitas pada anak usia sekolah sebesar 0,827 kali dibandingkan yang tidak melakukan aktivitas fisik dan perilaku makan sehat.

Hasil perbandingan prevalensi kekurusan dan kegemukan antara laki-laki dan perempuan pada studi di Kecamatan Sibolga Sambas, Kota Sibolga ini hampir sama dengan beberapa penelitian sebelumnya. Penelitian yang dilakukan oleh Pangani et al. (2016) pada anak sekolah usia 8-13 tahun di Kota Dares Salaam Tanzania, membuktikan bahwa prevalensi kekurusan pada siswa laki- laki (7\%) lebih tinggi dibandingkan perempuan $(5,5 \%)$ dan prevalensi kegemukan pada siswa perempuan $(26,7 \%)$ lebih tinggi daripada laki-laki (17\%). Sebaliknya, hasil yang ditemukan Kumah et al. (2015) pada siswa SD di Kumasi Metropolis Ghana membuktikan bahwa prevalensi kekurusan pada laki-laki $(2,6 \%)$ lebih rendah dibandingkan perempuan $(4,80 \%)$, sedangkan prevalensi kegemukan pada perempuan $(6 \%)$ lebih rendah daripada laki-laki (7\%). Hasil berbeda ditemukan juga oleh Ningsih et al. (2016) yang membuktikan bahwa proporsi kekurusan dan kegemukan pada siswa SD laki-laki (51,28\% dan 55\%) di Kecamatan Rangsang Kabupaten Kepulauan Meranti lebih tinggi dibandingkan dengan siswa perempuan (48,72\% dan $45 \%)$.

Sartika (2011) berpendapat bahwa kasus kegemukan bisa ditemukan lebih tinggi pada anak laki-laki maupun anak perempuan. Sama halnya dengan temuan studi di Kecamatan Sibolga Sambas Kota Sibolga ini yang membuktikan bahwa tidak terdapat perbedaan yang signifikan antara IMT laki- laki dan perempuan, Lissau et al. (2004) mengemukakan bahwa tidak terdapat hubungan antara jenis kelamin dengan kegemukan. Perbedaan pola lemak tubuh, Resting Energy Expenditure (REE) dan kebutuhan energi antara laki-laki dan perempuan menjadi bukti biologis perbedaan status kegemukan keduanya (Sweeting, 2008; Sartika, 2011). Ningsih et al. (2016) juga menambahkan bahwa pola aktivitas fisik anak laki-laki dengan anak perempuan berbeda. Anak laki-laki umumnya lebih aktif dalam beraktifitas dan bermain dibandingkan perempuan. Pola makan anak perempuan cenderung menyukai cemilan dibandingkan anak laki-laki yang pada umumnya sering melupakan jam makan akibat aktifitas yang berlebih. Hal ini juga bisa menjadi salah satu penyebab perbedaan status gizi kedua jenis kelamin tersebut.

Prevalensi kependekan (pendek dan sangat pendek) yang ditemukan di Kecamatan Sibolga Sambas Kota Sibolga pada studi ini lebih rendah $(3,78 \%)$ jika dibandingkan dengan prevalensi kependekan pada penelitian lainnya. Rahmawati \& Marfuah (2016) membuktikan prevalensi kependekan pada anak SD sebesar 6,96\%. Prevalensi kependekan di wilayah perkotaan menurut Purnamasari (2016) sebesar 4,5\% dan di pedesaan sebesar 7,9\%.

Kondisi kependekan terjadi akibat kekurangan asupan zat gizi dari diet yang berkualitas dan 
dikombinasikan dengan penyakit menular serta masalah lingkungan dalam jangka panjang. Kondisi ini bersifat irreversible (tidak dapat kembali dan diulang) sehingga sulit untuk diperbaiki dan akan terjadi seumur hidup (WHO, 2014). Kependekan pada anak dapat menurunkan kualitas sumber daya manusia. Kependekan pada anak terbukti dapat menurunkan perkembangan kognitif, menghambat tumbuh kembang, mudah terserang penyakit, serta memperlambat masa untuk dapat masuk sekolah yang kesemuanya itu akan berakibat pada penurunan produktivitas ketika dewasa (Chahyanto, 2015).

Kejadian kependekan pada anak sekolah dipengaruhi oleh berbagai faktor. Mesfin et al. (2015) membuktikan bahwa faktor risiko kependekan 1.71 kali lebih besar pada anak yang lahir dari ibu bekerja daripada anak yang lahir dari ibu rumah tangga. Selain itu, risiko kependekan 1.59 kali lebih besar pada anak-anak yang menderita penyakit selama 2 minggu terakhir dibandingkan anak- anak yang sehat.

Khuwaja et al. (2005) berpendapat bahwa jenis kelamin anak, usia anak, dan pekerjaan ayah merupakan faktor risiko kependekan pada anak sekolah usia 6-12 tahun di wilayah pedesaan. Namun, dalam studi yang dilakukan di Kecamatan Sibolga Sambas Kota Sibolga ini tidak ditunjukkan adanya perbedaan yang signifikan antara tinggi badan laki-laki dengan tinggi badan perempuan.

Prevalensi kekurusan, kegemukan, dan kependekan di Kecamatan Sibolga Sambas Kota Sibolga ini berbeda dengan penelitian yang dilakukan sebelumnya. Muthuri et al. (2014) berpendapat bahwa insiden gemuk dan obesitas lebih sering terjadi di sekolah swasta menengah dengan biaya tinggi daripada sekolah negeri. Pendapat ini diperkuat oleh Pangani et al. (2016) yang membuktikan bahwa prevalensi gemuk dan obesitas yang lebih tinggi pada siswa di SD swasta $(22,2 \%$ dan $11,4 \%)$ daripada di sekolah negeri $(12,1 \%$ dan 3,8\%). Perbedaan hasil ini dapat disebabkan karena kondisi sekolah swasta di wilayah Kecamatan Sibolga Sambas Kota Sibolga tidak semuanya termasuk sekolah swasta menengah dengan biaya yang tinggi sehingga tidak semua siswa yang bersekolah di sekolah swasta merukapakan anak dari orangtua dengan pendapatan yang tinggi.

Studi ini hanya menggambarkan prevalensi status gizi secara deskriptif tanpa melihat faktor-faktor risiko yang mempengaruhi status gizi tersebut. Oleh karena itu, perlu dilakukan studi analisis faktor determinan apa saja yang mempengaruhi status gizi kegemukan, kekurusan, dan kependekan pada anak $\mathrm{SD} /$ sederajat di Kecamatan Sibolga Sambas Kota Sibolga dengan sampel yang lebih besar.

\section{KESIMPULAN}

Kesimpulan studi ini adalah kondisi kekurusan, kegemukan, dan kependekan masih ditemukan pada anak siswa Sekolah Dasar/sederajat (SD/sederajat) kelas 1 di Kecamatan Sibolga Sambas Kota Sibolga dengan prevalensi $15,12 \%, 4,94 \%$, dan 3,78\%. Angka prevalensi yang tersedia ini dapat menambah database status gizi anak sekolah serta dijadikan acuan dalam menentukan kebijakan dan program intervensi sensitif dan spesifik untuk mencegah peningkatan prevalensi kekurusan dan kependekan, serta menurunkan kegemukan.

\section{UCAPAN TERIMA KASIH}

Terimakasih kepada UPTD Puskesmas Pelabuhan Sambas dan Dinas Kesehatan Kota Sibolga yang telah memberikan izin dalam penggunaan data untuk analisis ini. Terimakasih dan apresiasi yang sebesarbesarnya disampaikan juga kepada Bapak H. M. Syarfi Hutauruk selaku Walikota Sibolga yang telah mendukung dan mengarahkan kegiatan ini.

\section{REFERENSI}

Almatsier, S. (2006). Prinsip Dasar Ilmu Gizi. Jakarta: Gramedia Pustaka Utama. Baker, J.L., Olsen, L.W., \& Sorensen, T.I.A. (2007). Chilhood body-mass index and the risk of coronary hearth disease in Adulthood. The New England Journal of Medicine 357(23): 2329-2337.

Best, C., Neufingerl, N., Van Geel, L., Van Des Briel, T., \& Osendarp, S. (2010). The nutritional status of school-aged children: Why should we care? Food and Nutrition Bulletin 31(3): 400-417.

Chahyanto, B.A. (2015). Stunting dan pencegahannya melalui gerakan 1000 hari pertama kehidupan (1000 HPK). BIMGI 3(2): 36-42.

Collins, A.E., Pakiz, B., \& Rock, C.L. (2008). Factors associated with obesity in Indonesian adolescents. International Journal of Pediatric Obesity 3(1): 58-64.

Djaiman, S.P.H., Sihadi, Sari, K., \& Kusumawardani, N. (2017). Meta analisis: Pencegahan obesitas 
pada anak sekolah. Media Litbangkes 27(1): 39-48.

Jahri, I.W., Suyanto, \& Ernalia, Y. (2016). Gambaran status gizi pada siswa sekolah dasar Kecamatan Siak Kecil Kabupaten Bengkalis. JOM FK 3(2): 1-17.

Katier, N.V.P., Rooman, R.P., Haas, L., Verhulst, S.L., Desager, K.N., Ramet, J., \& Suys, B.E. (2008). Early cardiac abnormalities in obese children: Importance of obesity per se versus associated cardiovascular risk factors. Pediatric Research 64(2): 205-209.

[Kemenkes RI] Kementerian Kesehatan Republik Indonesia. (2010). Petunjuk Teknis Penjaringan Kesehatan Anak Sekolah Dasar. Jakarta: Direktorat Bina Kesehatan Anak, Dirjen Bina Kesehatan Masyarakat Kemenkes RI.

[Kemenkes RI] Kementerian Kesehatan Republik Indonesia. (2011). Keputusan Menteri Kesehatan Republik Indonesia Nomor: 1995/MENKES/SK/XII/2010 tentang Standar Antropometri Penilaian Status Gizi Anak. Jakarta: Direktorat Bina Gizi, Dirjen Bina Gizi dan Kesehatan Ibu dan Anak Kemenkes RI.

[Kemenkes RI] Kementerian Kesehatan Republik Indonesia. (2013). Riset Kesehatan Dasar. Jakarta: Badal Penelitian dan Pengembangan Kesehatan Kemenkes RI.

[Kemendikbud RI] Kementerian Pendidikan dan Kebudayaan Republik Indonesia. (2017). Peraturan Menteri Pendidikan dan Kebudayaan Republik Indonesia Nomor 17 tentang Penerimaan Peserta Didik Baru pada Taman Kanak-Kanak, Sekolah Dasar, Sekolah Menengah Pertama, Sekolah Menengah Atas, Sekolah Menengah Kejuruan, atau Bentuk Lain yang Sederajat. Jakarta: Menteri Pendidikan dan Kebudayaan Republik Indonesia.

Khuwaja, S., Selwyn, B.J., \& Shah, S.M. (2005). Prevalence and correlates of stunting among primary school children in Rural Areas of Southern Pakistan. Journal of Tropical Pediatrics 51(2): 72-77.

Kumah, D.B., Akuffo, K.O., Abaka-Cann, J.E., Affram, D.E., \& Osae, E.A. (2015). Prevalence of overweight and obesity among students in the Kumasi Metropolis. Journal of Nutrition and Metabolism 2015: 1-4.

Lestari, I.D., Ernalia, Y., \& Restuastuti, T. (2016). Gambaran status gizi pada siswa sekolah dasar Kecamatan Bangko Kabupaten Rokan Hilir. JOM FK 3(2): 1-14.

Lissau, I., Overpeck, M.D., Ruan, W.J., Due, P., Holstein, B.E., Hediger, M.L., \& Group atHB1SaCOW. (2004). Body mass index and overweight in adolescents in 13 European Countries, Israel, and the United States. Arch Pediatr Adolesc Med 158: 27-33.

Maleke, V., Umboh, A., Pateda, V. (2015) Hubungan status gizi dengan prestasi belajar siswa sekolah dasar di Kecamatan Modoinding. Jurnal e- Clinic 3(3): 749-753.

Mariyati, L.I. (2017). Usia dan jenis kelamin dengan kesiapan masuk sekolah dasar. Prosiding Seminar Nasional Psikologi UMG: 331-344.

Mesfin, F., Berhane, Y., \& Worku, A. (2015). Prevalence and associated factors of stunting among primary school children in Eastern Ethiopia. Nutrition and Dietary Supplements 7: 61-68.

Muthuri, S.K., Francis, C.E., Wachira, L.J., Leblanc, A.G., Sampson, M., Onywera, V.O., \& Tremblay, M.S. 2014. Evidence of an overweight/obesity transition among school-aged children and youth in Sub-Saharan Africa: a systematic review. PloS One 9(3):1-26.

Ningsih, Y.A., Suyanto, \& Restuastuti, T. (2016). Gambaran status gizi pada siswa sekolah dasar Kecamatan Ransang Kabupaten Kepulauan Meranti. JOM FK 3(2): 1-11.

Pangani, I.N., Kiplamai, F.K., Kamai, J.W., \& Onywera, V.O. (2016). Prevalence of overweight and obesity among primary school children aged $8-13$ years in Dar es Salaam City, Tanzania. Advances in Preventive Medicine (2016): 1-5.

Peraturan Pemerintah. (2010). Peraturan Pemerintah Republik Indonesia Nomor 17 tentang Pengelolaan dan Penyelenggaraan Pendidikan. Jakarta: Pemerintah Republik Indoensia.

[PERGIZI PANGAN Indoensia] Perhimpunan Pakar Gizi dan Pangan Indonesia. (n.d.). Cakrem Pemantauan Berat Badan dan Tinggi Badan.

Purnamasari, D.U., Dardjito, E., \& Kusnandar. (2016). Status gizi berdasarkan indeks IMT/U dan TB/U pada anak baru masuk sekolah dasar di perkotaan dan pedesaan. Jurnal Kesmasindo 8(1): 85-97.

Rachmi, C.N., Li, M., \& Baur, L.A. (2017). Overweight and obesity in Indonesia: prevalence and risk factors-a literature review. Public Health 147: 20-29.

Rahmawati, T. \& Marfuah, D. (2016). Gambaran status gizi pada anak sekolah dasar. Profesi 14(1)L 72- 
76.

Rizally, M.A. (2014). Korelasi antara usia kronologis awal masuk sekolah terhadap prestasi belajar. EJUPEKhu 3(3): 140-148.

Sa'adah, R.H., Herman, R.B., \& Sastri, S. (2014). Hubungan status gizi dengan prestasi belajar siswa Sekolah Dasar Negeri 01 guguk Malintang, Kota Padangpanjang. Jurnal Kesehatan Andalas 3(3): 460-465.

Sartika, R.A.D. (2011). Prevalensi dan determinan kelebihan berat badan dan kegemukan pada anak berusia 5-15 tahun. Jurnal Kesehatan Masyarakat Nasional 5(6): 262-268.

Sulistyoningsih, H. (2011). Gizi untuk Kesehatan Ibu dan Anak. Yogyakarta: Graha Ilmu.

Sweeting, H.N. (2008). Gendered dimensions of obesity in chilhood and adolescence. Nutrition Journal 7(1): 1-14.

[WHO] World Health Organization. (2014) Childhood Stunting: Challenges and Opportunities. Report of a Promoting Healthy Growth and Preventing Childhood Stunting Colloquium. Generva: World Health Organization. 